\title{
MICROSTRUCTURE, MAGNETIC AND MECHANICAL PROPERTIES OF THE BULK AMORPHOUS ALLOY $\mathrm{Fe}_{61} \mathrm{Co}_{10} \mathrm{Ti}_{4} \mathrm{Y}_{5} \mathrm{~B}_{20}$
}

\section{MIKROSTRUKTURA, MAGNETNE IN MEHANSKE LASTNOSTI MASIVNE AMORFNE ZLITINE Fe61 Co10Ti4Y $5 B_{20}$}

\author{
Katarzyna Bloch, Marcin Nabiałek, Joanna Gondro \\ Czestochowa University of Technology, Faculty of Materials Processing Technology and Applied Physics, Institute of Physics, Czestochowa, \\ Poland \\ 23kasia1@wp.pl
}

Prejem rokopisa - received: 2014-08-01; sprejem za objavo - accepted for publication: 2014-09-30

doi:10.17222/mit.2014.175

This paper presents the results of the studies into the microstructure, the magnetic and mechanical properties of bulk amorphous alloy samples. The samples were produced in the form of rods, using the suction-casting method. The structure and microstructure of the prepared samples were examined using an X-ray diffractometer, a scanning electron microscope and a computer tomograph. The magnetic and mechanical properties were studied using a Lakeshore vibrating-sample magnetometer, a Zwick testing machine and a FutureTech microhardness tester.

On the basis of the obtained results, it was found that, throughout their volumes, the investigated rods have an amorphous structure. Using computer tomography, three-dimensional images of the tested samples were reconstructed, enabling the imaging of the material defects occurring throughout the bulk volumes of the samples. Additionally, the tested Fe-based material should be included in the subset of the electrotechnical materials exhibiting good soft magnetic and mechanical properties. In view of their properties, these materials can be successfully used in energy-efficient transformers, replacing the conventional Fe-Si steel in this and other applications.

Keywords: bulk amorphous alloys, electron scanning microscopy, computer tomography, saturation magnetization, coercivity

Članek predstavlja rezultate študija mikrostrukture, magnetnih in mehanskih lastnosti vzorcev masivne amorfne zlitine. Le-ti so bili izdelani $\mathrm{v}$ obliki palic z uporabo ulivanja z nasesavanjem. Struktura in mikrostruktura pripravljenih vzorcev je bila preiskovana $\mathrm{z}$ rentgenskim difraktometrom, z vrstičnim elektronskim mikroskopom in z računalniškim tomografom. Magnetne in mehanske lastnosti so bile preiskovane $\mathrm{z}$ magnetometrom $\mathrm{z}$ vibrirajočim vzorcem Lakeshore, $\mathrm{s}$ preizkusno napravo Zwick in $\mathrm{z}$ merilnikom mikrotrdote FutureTech.

Dobljeni rezultati so pokazali, da imajo preiskovane palice po vsem volumnu amorfno strukturo. Z računalniško tomografijo so bile pripravljene 3D-slike preiskovanih vzorcev, kar omogoča ugotavljanje napak v materialu, ki se pojavljajo po vsem volumnu vzorca. Preizkušeni materiali na osnovi železa naj bi bili vključeni v podskupino materialov za elektrotehniko z dobrimi mehkomagnetnimi in mehanskimi lastnostmi. Glede na njihove lastnosti bi bili lahko ti materiali uspešno uporabljeni za energijsko učinkovite transformatorje, kjer bi nadomestili Fe-Si-jekla, in tudi na drugih področjih.

Ključne besede: masivne amorfne zlitine, vrstična elektronska mikroskopija, računalniška tomografija, nasičenje magnetenja, koercitivnost

\section{INTRODUCTION}

Industrial organizations are continuously searching for new materials that will exhibit much-improved properties over those that are currently used. Such materials include bulk amorphous alloys, which, compared with crystalline materials with the same chemical compositions, exhibit much more useful property parameters. ${ }^{1,2}$ The reason for the improvement of these properties is the specific structure of the amorphous materials., ${ }^{3,4}$ One of the most interesting groups of amorphous alloys includes some of the iron-based alloys, which exhibit excellent magnetic and mechanical properties. ${ }^{5-9}$

\section{METHOD}

In these investigations, the bulk amorphous alloy of $\mathrm{Fe}_{61} \mathrm{Co}_{10} \mathrm{Ti}_{4} \mathrm{Y}_{5} \mathrm{~B}_{20}$ was used, in the form of rods with a length of $2 \mathrm{~cm}$ and a diameter of $1 \mathrm{~mm}$. The ingots of the alloy were obtained by arc-melting and mixing highpurity elements under an argon atmosphere. The amorphous rods were produced using the suction-casting method involving the quenching of the molten material in a water-cooled, copper die. In order to avoid oxidizing the samples, the whole production process was carried out in a protective argon atmosphere. The microstructure and structure of the alloy were investigated by means of $\mathrm{X}$-ray diffractometry, electron scanning microscopy and computer tomography. The BRUKER X-ray diffractometer was equipped with a lamp with a Co-K $\alpha$ source. Investigations were carried out over the $2 \theta$ range from $30^{\circ}$ to $120^{\circ}$, with a measurement step of $0.02^{\circ}$ and the time per step of $5 \mathrm{~s}$. Images of the material surface were obtained using a Zeiss SUPRA 35 high-resolution scanning electron microscope, utilizing the detection of secondary electrons (SE) and having an acceleration voltage of 
$25 \mathrm{kV}$. In order to analyse the chemical composition of the samples, an EDAX TRIDENT XM4 energy-dispersive X-ray Spectrometer (EDS) was used. A reconstruction of the surfaces of the samples was achieved using a BRUKER Mikro-CT SkyScan 1172 computer tomograph. The operating parameters, such as the voltage, the filter type and the exposure time were optimized to obtain the greatest contrast. The investigations were performed with a resolution (pixel size) of $2.38 \mathrm{~mm}$, for the rotation angle of $360^{\circ}$, a step of $0.3^{\circ}$ and the exposure time of $1.2 \mathrm{~ms}$. Diffraction rings were reduced by oscillating the measurement table with an amplitude setting of 50. All the reconstructions were obtained utilizing dedicated NRecon and CTAN (Bruker) software and the editing was visualized using DataViewer and CTVol (Bruker) software.

The microhardness of the samples was measured using the Vickers method and a FutureTech FM hardness tester, with a measurement time of $10 \mathrm{~s}$ and an applied force of $490.3 \mathrm{mN}$.

Three-point bending tests for metallic glasses were performed on the investigated material. A Zwick 005 testing machine was used for this test, with a crosshead speed of $1 \mathrm{~mm} / \mathrm{min}$; the spacing and diameter of the supports were $5 \mathrm{~mm}$ and $2 \mathrm{~mm}$, respectively. The tension was calculated from the following equation:

$$
\sigma=\frac{3 F l}{2 b h^{2}}(\mathrm{MPa})
$$

where: $F$ - force, $l$ - support spacing, $b$ - sample width, $h$ - sample thickness.

Static hysteresis loops were obtained using a LakeShore 7103 vibrating-sample magnetometer (VSM). From the analysis of the static hysteresis loops, parameters such as the saturation magnetization, the coercivity and the stiffness parameter of the spin wave $\left(D_{\mathrm{sp}}\right)$ were found.

\section{RESULTS}

Figure 1 shows the $\mathrm{X}$-ray diffraction pattern obtained for the sample of the $\mathrm{Fe}_{61} \mathrm{Co}_{10} \mathrm{Ti}_{4} \mathrm{Y}_{5} \mathrm{~B}_{20}$ alloy.

In the obtained X-ray diffraction pattern, only a single broad maximum is present, indicating the amorphicity of the material. ${ }^{10}$

In Figure 2, SEM images of the surface of an investigated rod and the results obtained with an EDS ana-

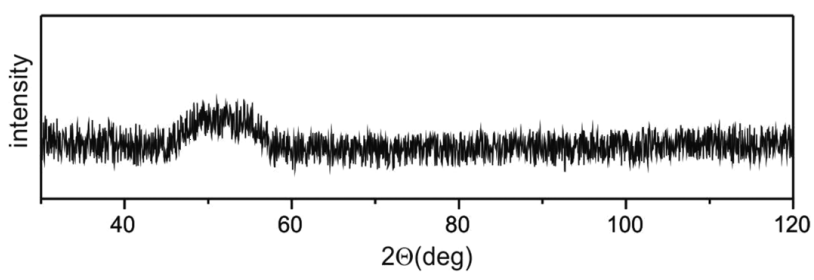

Figure 1: X-ray diffraction pattern for the bulk amorphous $\mathrm{Fe}_{61} \mathrm{Co}_{10} \mathrm{Ti}_{4} \mathrm{Y}_{5} \mathrm{~B}_{20}$ alloy

Slika 1: Rentgenogram masivne amorfne zlitine $\mathrm{Fe}_{61} \mathrm{Co}_{10} \mathrm{Ti}_{4} \mathrm{Y}_{5} \mathrm{~B}_{20}$ lysis, are presented. The SEM image of the surface reveals the consequence of an uneven cooling speed during the production process. Discontinuities along the longitudinal surface of the rod are the reason for an inhomogeneous stress distribution in the sample crosssection. The influence of these stresses on the type of breakthrough is visualised in Figure $\mathbf{2 b}$. The zones with different breakthrough characteristics are marked with white circles. In Figure 2e three beams of the stress bands are visible, typical of those observed in the breakthroughs of the amorphous samples. Within the circumference zone of about $70 \mu \mathrm{m}$ numerous gas bubbles can be seen, which were created during the production process of the rods. The elimination of the pores existing in this zone is difficult and requires maintenance of stable conditions during the whole production process. During the decohesion process, parallel displaced veins were created (Figure 2c). Within the boundaries of these veins, free volumes are visible due to the decomposition of the material. This can be connected with the fluctuations of the chemical composition and density existing in the alloy. Within the limits of the investigated breakthroughs, poorly developed scale-like structures were also observed (Figure 2d), indicating different levels of relaxation. Throughout the whole volume of the breakthrough, point imperfections were observed on the surface (Figure 2f).

The X-ray microanalysis demonstrated that these areas are not crystallites and that they have a different chemical composition, compared with the surrounding amorphous matrix. In the investigated areas, the $\mathrm{Y}$ and Fe atoms were subjected to regrouping processes. An increase in the Y content, to amount fraction $10 \%$, was observed with a simultaneous decrease in the Fe content of more than $3 \%$, compared with the nominal alloy composition. This result may indicate a tendency to create Y-rich conglomerates, which could be the origin of the

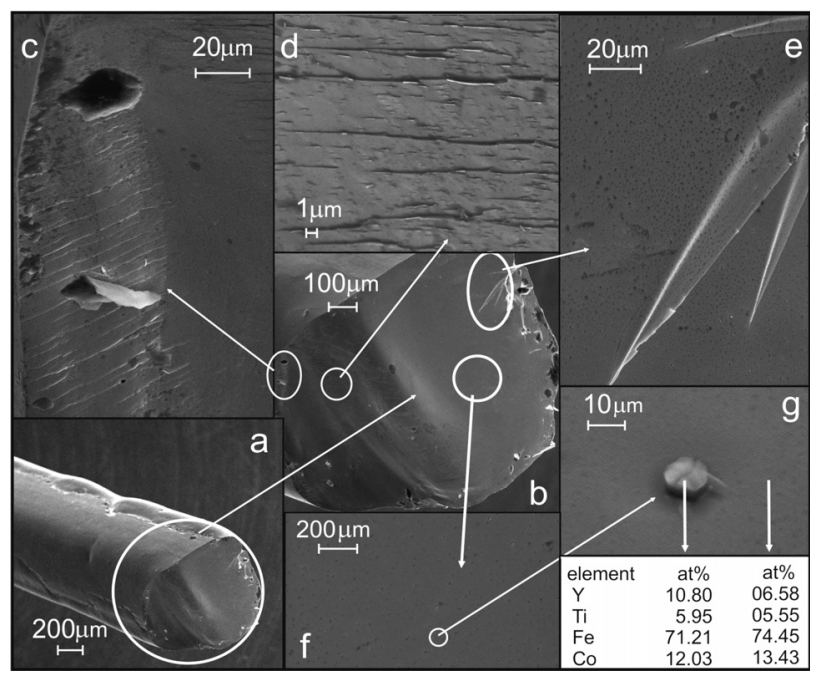

Figure 2: SEM images for the bulk amorphous $\mathrm{Fe}_{61} \mathrm{Co}_{10} \mathrm{Ti}_{4} \mathrm{Y}_{5} \mathrm{~B}_{20}$ alloy

Slika 2: SEM-posnetki masivne amorfne zlitine $\mathrm{Fe}_{61} \mathrm{Co}_{10} \mathrm{Ti}_{4} \mathrm{Y}_{5} \mathrm{~B}_{20}$ 


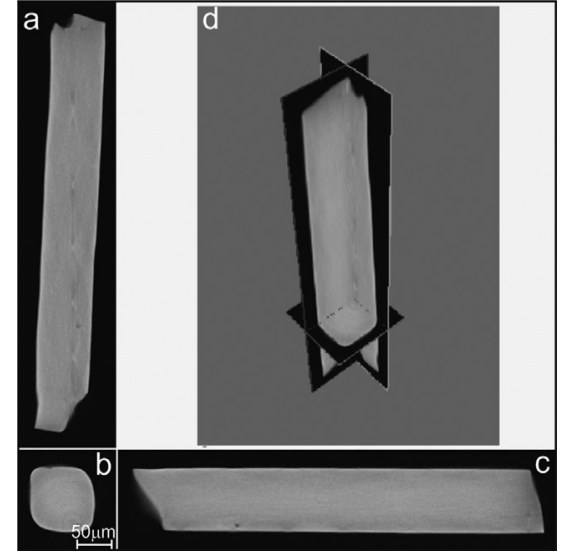

Figure 3: Cross-sections: a) lengthwise, b) transverse, c) sagittal and d) their spatial representation

Slika 3: Prerezi: a) vzdolžni, b) prečni, c) sagitalni in d) njihov prostorski prikaz

two metastable crystalline phases: $\mathrm{Y}_{5} \mathrm{Co}, \mathrm{Fe}_{17} \mathrm{Y}_{2}$ and $\alpha$-Fe phase, created during the primary crystallization.

The 3-D image reconstructions, obtained in three planes and then superposed, are presented in Figure 3.

The presented transmission images (Figure 3) are typical of a sample with one phase, which is in agreement with the X-ray results.

The magnetic parameters, including the saturation magnetization and the value of the coercive field were obtained from the analysis of the static hysteresis loops (Figure 4). The investigated alloy is a ferromagnetic material, exhibiting soft magnetic properties, with a relatively high value of the saturation magnetization and a small value of the coercivity. These properties make it attractive as a material for low-loss transformer cores working at high frequencies.

The Holstein-Primakoff paraprocess ${ }^{11}$ is one of the high-field factors influencing the magnetization process in the range of the magnetic field above the anisotropy

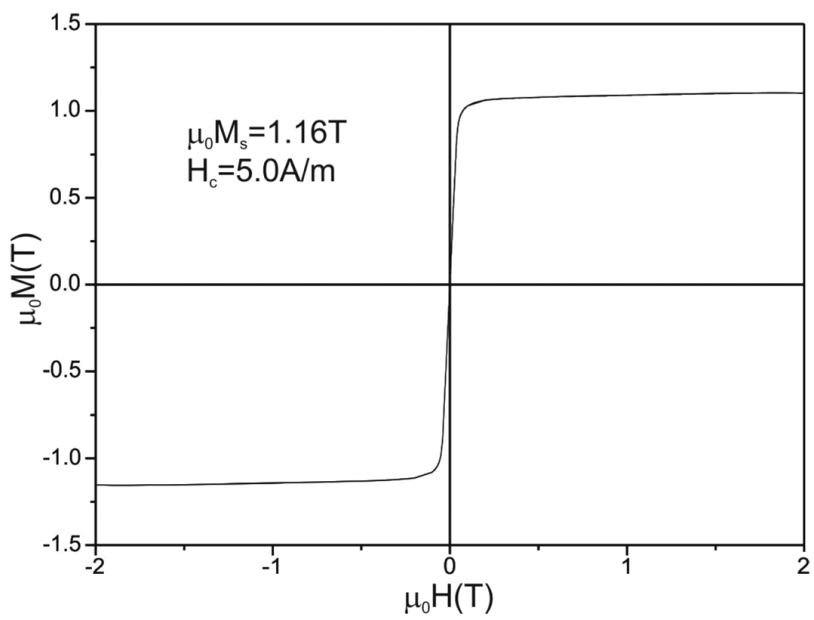

Figure 4: Static hysteresis loop for the $\mathrm{Fe}_{61} \mathrm{Co}_{10} \mathrm{Ti}_{4} \mathrm{Y}_{5} \mathrm{~B}_{20}$ alloy in the form of a rod

Slika 4: Statična histerezna zanka zlitine $\mathrm{Fe}_{61} \mathrm{Co}_{10} \mathrm{Ti}_{4} \mathrm{Y}_{5} \mathrm{~B}_{20}$ v obliki palice

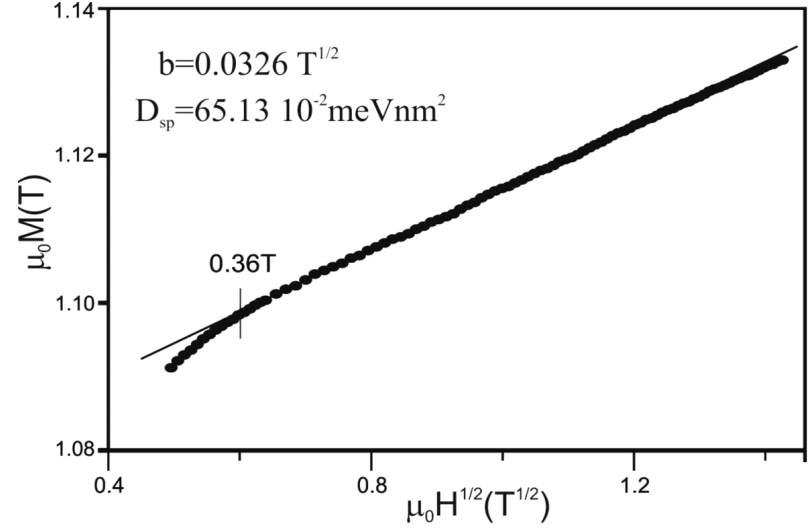

Figure 5: Magnetization as a function of the magnetic field for the bulk amorphous $\mathrm{Fe}_{61} \mathrm{Co}_{10} \mathrm{Ti}_{4} \mathrm{Y}_{5} \mathrm{~B}_{20}$ alloy in the form of a rod

Slika 5: Magnetizacija $\mathrm{v}$ odvisnosti od magnetnega polja masivne amorfne zlitine $\mathrm{Fe}_{61} \mathrm{Co}_{10} \mathrm{Ti}_{4} \mathrm{Y}_{5} \mathrm{~B}_{20} \mathrm{v}$ obliki palice

field. A linear relation $\mu_{0} \mathrm{M}\left(\sqrt{\mu_{0} H}\right)$ is presented in Figure 5.

On the basis of the following relationship:

$$
b=3.54 g \mu_{0} \mu_{\mathrm{B}} \sqrt{\left(1 / 4 \pi D_{\mathrm{sp}}\right)^{3}} k t \sqrt{g \mu_{\mathrm{B}}}
$$

(where: $g$ - Lande split coefficient, $\mu_{\mathrm{B}}$ - Bohr magneton, $\mu_{0}$ - magnetic permeability of a vacuum, $k$ - Boltzmann constant, $T$ - temperature, $b$ - linear fit coefficient of the Holstein-Primakoff paraprocess ${ }^{11}$ ) the spin-wave stiffness parameter $\left(D_{\mathrm{sp}}\right)$ was calculated; this parameter is described with the following equation:

$$
D_{\mathrm{sp}}=\sum S_{i} J\left(\vec{r}_{i}\right) \vec{r}_{i}^{2} \cos ^{2}\left(\vec{k}, \vec{r}_{i}\right)
$$

where: $S_{i}-$ spin in the $r_{i}$ position against the central atom, $J\left(r_{i}\right)$ - exchange integral between the central atom and an atom in the $\vec{r}_{i}$ position, $\vec{k}$ - wave vector.

In the case of the materials with an amorphous structure, $\vec{r}_{i}$ denotes the locations of the closest magnetic atoms within the vicinity of the central atom. If the investigated alloy has a high value of this parameter this indicates the creation of short-range chemical order.

Exemplar imprints of the Vickers pyramids are presented in Figure 6.

The results of five microhardness measurements and their average value are listed in Table $\mathbf{1 .}$

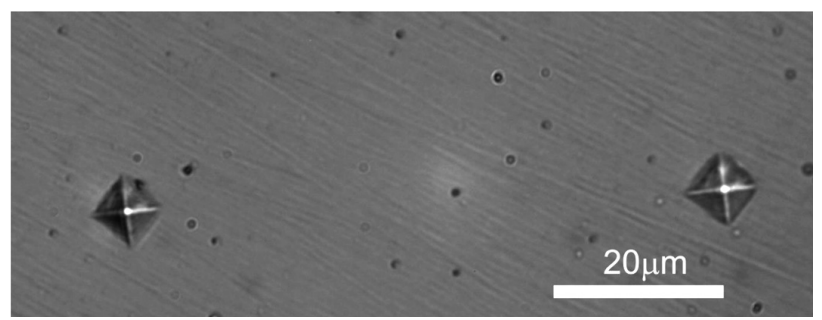

Figure 6: Vickers imprints obtained for the investigated alloy Slika 6: Odtiska meritve trdote po Vickersu na preiskovani zlitini 
Table 1: Hardness-measurement results

Tabela 1: Rezultati meritve trdote

\begin{tabular}{|c|c|}
\hline Item number & Microhardness $\left(\mathrm{HV}_{0.05}\right)$ \\
\hline 1 & 1362 \\
\hline 2 & 1339 \\
\hline 3 & 1491 \\
\hline 4 & 1454 \\
\hline 5 & 1123 \\
\hline Average & 1354 \\
\hline
\end{tabular}

The investigated amorphous alloy, $\mathrm{Fe}_{61} \mathrm{Co}_{10} \mathrm{Ti}_{4} \mathrm{Y}_{5} \mathrm{~B}_{20}$, possesses a high average value of microhardness, more than $100 \mathrm{HV}$ higher than the value for the Fe-B amorphous alloys ${ }^{12}$.

The investigated rod was subjected to the three-point bending test for metallic glasses. The maximum value of the bending strength parameter was found to be 465.75 $\mathrm{MPa}$ which is typical for this type of materials ${ }^{13-15}$.

\section{CONCLUSIONS}

The investigation described in this paper involved the application of the suction-casting method of producing an alloy, with strict adherence to the rules for the production parameters. This resulted in a repeatable production process for the manufacture of a bulk amorphous alloy $\mathrm{Fe}_{61} \mathrm{Co}_{10} \mathrm{Ti}_{4} \mathrm{Y}_{5} \mathrm{~B}_{20}$ in the form of a rod with a length of $2 \mathrm{~mm}$ and a diameter of $1 \mathrm{~mm} \cdot{ }^{10}$ On the basis of the structural and microstructural investigations, it can be concluded that regions of a slightly heterogeneous chemical composition occur within the volume of the sample, i.e., locally, the chemical composition varies slightly around the stoichiometric formula. On the surface of the breakthrough, numerous cylindrical 'islands' with a high $\mathrm{Y}$ content are present (Figure $\mathbf{2 g}$ ). The fluctuations in the chemical composition and density are visible in the SEM images; such fluctuations can provide energetically favourable locations for the emergence of crystalline-phase nuclei, which are the result of the primary crystallization. In the breakthrough of the rod (Figure 2) various types of structures were observed. The variation from a smooth to a scale-like structure, with numerous breakdowns, indicates different stress distributions of the structure. 3-D reconstructions of the rod images did not reveal any imperfections in the form of the pores (Figure 3). The investigated material is ferromagnetic with a high value of the saturation magnetization and a low coer- civity. These values are comparable to those obtained for $\mathrm{FeSi}$ steels used for transformer/inductor cores. However, the FeSi steels exhibit a high magnetostriction compared with the amorphous materials ${ }^{10}$. From the analysis of the high-field Holstein-Primakoff paraprocess, parameter $D_{\text {sp }}$ was found, its value indicating a high concentration of magnetic atoms per unit volume, and confirming the high value of the saturation magnetization ${ }^{11}$. The investigated alloy has a microhardness value of approximately $1350 \mathrm{HV}$, which is slightly higher than that for the iron-based bulk amorphous alloys ${ }^{13-16}$. In conclusion, the investigated material has strong application prospects, especially in the electrotechnical industry where it may be used as a material for efficient magnetic cores.

\section{REFERENCES}

${ }^{1}$ H. Chirac, N. Lupu, Materials Science and Engineering A, 375-377 (2004), 255-259, doi:10.1016/j.msea.2003.10.110

${ }^{2}$ K. Błoch, Journal of Magnetism and Magnetic Materials, 390 (2015), 118-122, doi:10.1016/j.jmmm.2015.04.032M

${ }^{3}$ A. Inoue, Materials Science and Engineering, 226-228 (1997), 357-363, doi:10.1016/S0921-5093(97)80049-4

${ }^{4}$ R. Hasegawa, Journal of Magnetism and Magnetic Materials, 41 (1984), 79-85, doi:10.1016/0304-8853(84)90142-2

${ }^{5}$ K. Błoch, M. Nabiałek, P. Pietrusiewicz, J. Gondro, M. Dośpial, M. Szota, K. Gruszka, Acta Physica Polonica A, 126 (2014) 1, 108-109, doi:10.12693/APhysPolA.126.108

${ }^{6}$ K. Sobczyk, J. Świerczek, J. Gondro, J. Zbroszczyk, W. Ciurzyńska, J. Olszewski, P. Brągiel, A. Łukiewska, J. Rzącki, M. Nabiałek, Journal of Magnetism and Magnetic Materials, 324 (2012), 540-549, doi:10.1016/j.jmmm.2011.08.038

${ }^{7}$ H. Jian, W. Luo, S. Tao, M. Yan, Journal of Alloys and Compounds, 505 (2010), 315-318, doi:10.1016/j.jallcom.2010.06.061

${ }^{8}$ M. Nabiałek, Journal of Alloys and Compounds, 642 (2015), 98-103, doi:10.1016/j.jallcom.2015.03.250

${ }^{9}$ K. Błoch, M. Nabiałek, Acta Physica Polonica A, 127 (2015), 413-414, doi:10.12693/APhysPolA.127.413

${ }^{10}$ D. Szewieczek, J. Tyrlik-Held, S. Lesz, Journal of Materials Processing Technology, 109 (2001), 190-195, doi:10.1016/S09240136(00)00795-0

${ }^{11}$ T. Holstein, H. Primakoff, Physical Review, 58 (1940), 1098-1113, doi:10.1103/PhysRev.58.1098

${ }^{12}$ A. Inoue, Acta Materialia, 48 (2000), 279-306, doi:10.1016/S13596454(99)00300-6

${ }^{13}$ D. Szewieczek, S. Lesz, Journal of Materials Processing Technology, 162-163 (2005), 254-259, doi:10.1016/j.jmatprotec.2005.02.017

${ }^{14}$ M. Nabialek et al., Journal of Alloys and Compounds, 509S (2011), S155-S160, doi:10.1016/j.jallcom.2011.01.158

${ }^{15}$ M. Nabiałek et al., Phys. Status Solidi C, 7 (2010) 5, 1428-1431, doi:10.1002/pssc.200983393

${ }^{16}$ D. Jenko, Mater. Tehnol., 45 (2011) 4, 303-310 